\title{
Incidence of Staphylococcus aureus on equipment from a gym of physical activities in
}

\author{
Alfenas - MG \\ Incidência de Staphylococcus aureus em equipamentos de uma academia de atividades físicas em \\ Alfenas - MG \\ Incidencia de Staphylococcus aureus en equipos de un gimnasio de actividades físicas en Alfenas -
}

MG

Received: 08/31/2021 | Reviewed: 09/09/2021 | Accept: 09/09/2021 | Published: 09/12/2021

Evandro Neves Silva
ORCID: https://orcid.org/0000-0002-4145-1401
Universidade José do Rosário Vellano, Brazil
E-mail: evandroneves95@ @otmail.com
Thaís Cristina Ferreira dos Santos
ORCID: https://orcid.org/0000-0003-2590-9432
Universidade José do Rosário Vellano, Brazil
E-mail: thaiscfs18@ gmail.com
Bethânia Elias Costa
ORCID: https://orcid.org/0000-0002-8514-9028
Universidade José do Rosário Vellano, Brazil
E-mail: bethaniaelias@ hotmail.com
Mariely Simone Lopes Corrêa
ORCID: https://orcid.org/0000-0002-7032-1606
Universidade José do Rosário Vellano, Brazil
E-mail: mariely_correa @ hotmail.com
Gabriel Henrique Ferracioli Alvarenga
ORCID: https://orcid.org/0000-0002-4131-9320
Universidade José do Rosário Vellano, Brazil
E-mail: gabrhielferraccioli@ @mail.com
Édina de Fátima Aguiar
ORCID: https://orcid.org/0000-0002-7883-5628
Universidade José do Rosário Vellano, Brazil
E-mail: edina.aguiar@unifenas.br
Andressa Santanna Natel
And

\begin{abstract}
With an increasing demand for gyms, especially during summer, the risk of contamination rises despite preventive care. In many sports, exercising must require attention to hygiene, mainly due to great chances of contracting diseases. Staphylococcus aureus has widely spread caused by its ability to express various virulence factors, which can cause diseases ranging from simple to most severe infections as a pathogen. This paper investigates the incidence of Staphylococcus aureus in equipment from a gym of physical activities in Alfenas-MG and identifies the appropriate level about the importance of cleaning equipment. In this study, three collections were carried out per equipment in different places, at three times; totaled 54 samples. Staphylococcus aureus was identified by sowing in Mannitol Salt Agar, medium coloration and colonial morphology, catalase, and coagulase tests. Twenty-nine samples obtained growth from the sowings, being positive for gram staining, catalase, and coagulase. In samples with micro-organisms
\end{abstract}


$(53.70 \%)$ and correspondents (50\%), gym-goers did not clean the equipment, and the others $(50 \%)$ only used the individual towel. Therefore, the measures that can decrease the incidence of micro-organisms, particularly Staphylococcus aureus, are disinfecting with $70 \%$ alcohol and disposable paper before and after manipulating equipment in a gym.

Keywords: Sanitation; Contamination in gyms; Microorganism; Staphylococcus aureus.

\section{Resumo}

Com aumento da procura, numa determinada época do ano; no verão, o risco de contaminação em academias aumenta ainda que os cuidados de prevenção sejam simples. Assim como em diversos esportes, a prática requer muita atenção com a higiene, pois as chances de se contrair doenças são grandes. O sucesso de Staphylococcus aureus como um agente patogênico é, em parte, devido à sua capacidade de expressar uma variedade de fatores de virulência, podendo provocar doenças que vão desde uma infecção simples, até as mais graves. Tendo por objetivo central investigar o índice de Staphylococcus aureus em aparelhos de academia de atividades físicas de Alfenas-MG e identificar o grau de conhecimento sobre a importância da higienização dos equipamentos, no presente estudo, realizou-se 3 coletas por equipamento em diferentes locais, em 3 momentos distintos; totalizadas 54 amostras. A identificação de Staphylococcus aureus, realizou-se por semeadura em Ágar Sal Manitol, coloração do meio e morfologia colonial, provas de catalase e coagulase. Das semeaduras, 29 amostras obtiveram crescimento, sendo positivas para coloração de gram, catalase e coagulase. Nas amostras com micro-organismos (53,70\%) e os entrevistados (50\%), frequentadores da academia, não realizam higienização nos equipamentos e os demais (50\%) só utilizam a toalha individual. Sendo assim, as medidas as quais podem diminuir a incidência de micro-organismos, em especial Staphylococcus aureus, é o uso de álcool $70 \%$ e papel descartável antes e após utilização do equipamento na academia.

Palavras-chave: Higienização; Contaminação em academias; Micro-organismo; Staphylococcus aureus.

\section{Resumen}

Con mayor demanda, en determinada época del año; en verano, el riesgo de contaminación en los gimnasios aumenta incluso si la atención preventiva es simple. Como en muchos deportes, la práctica requiere mucha atención a la higiene, ya que las posibilidades de contraer enfermedades son grandes. El éxito de Staphylococcus aureus como patógeno se debe, en parte, a su capacidad para expresar una variedad de factores de virulencia, que pueden causar enfermedades que van desde una simple infección hasta las más graves. Con el objetivo principal de investigar el índice de Staphylococcus aureus en equipos de gimnasia de actividad física en Alfenas-MG e identificar el grado de conocimiento sobre la importancia de la limpieza de equipos, en este estudio se realizaron 3 recolecciones por equipos en diferentes ubicaciones, en 3 diferentes veces; totalizaron 54 muestras. Staphylococcus aureus se identificó mediante la siembra en Manitol Salt Agar, coloración media y morfología colonial, pruebas de catalasa y coagulasa. De las siembras, 29 muestras obtuvieron crecimiento, siendo positivas para tinción de Gram, catalasa y coagulasa. En muestras con microorganismos $(53,70 \%)$ y encuestados $(50 \%)$, asistentes al gimnasio, no realizan limpieza de equipos y los demás (50\%) solo utilizan la toalla individual. Así, las medidas que pueden reducir la incidencia de microorganismos, especialmente Staphylococcus aureus, es el uso de alcohol al $70 \%$ y papel desechable antes y después de utilizar el equipo en el gimnasio.

Palabras clave: Saneamiento; Contaminación en gimnasios; Microorganismo; Staphylococcus aureus.

\section{Introduction}

In the 21st century, physical activities have gained significant importance due to the increasing amount of studies and lifestyle changes; according to Professor Leonardo Lima: "When a person exercises, the musculature works, and the alignment and support of the body improves" (Santos et al., 2007). Regular physical exercise promotes quality of life and can act on the immune response, reducing the risk of developing systemic inflammatory processes and stimulates cellular immunity against pathogens (Silveira et al., 2021; Nieman et al., 2019).

Physical activity is considered one of the main components of healthy living. In addition, to functions related to preventing excess body weight, systemic inflammation, and chronic non-communicable diseases, a potential benefit of exercise in reducing communicable diseases, including viral pathologies (Laddu et al., 2020). Before summer, the search for gyms increased by 30\%, according To Sebrae News Agency, which increases possible contamination in this environment. Moreover, during this season, the body is most vulnerable to be infected by fungi and bacteria. However, preventive care is simple. To have a healthy style is not only needed a simple physical shape. As in many sports, the practice requires much attention to hygiene (Silveira et al., 2020). 
A warning on the subject was exposed in the report of the National Athletic Trainers association in 2010. According to the document, skin diseases are extremely common in athletes, being responsible for more than $50 \%$ of the infectious diseases that affect competitors. For amateur sportsmen who attend gyms and locker rooms, the risk also exists (Brasil et al., 2015; Chen et al., 2020). One of the risks is the large exposure to microorganisms, specifically bacteria.

The Scottish surgeon Alexander Ogston described Staphylococcus aureus (S. aureus) in 1880, who isolated this bacterium from a wound and proved its importance as pathogenic pus. S. aureus is a gram-positive bacterium (from the Greek kókkos, "the grain"), about $1 \mu \mathrm{m}$ in diameter, that arranges itself in dense clusters (Figure 1) (Mrochen et al., 2020; Everton et al., 2020).

In the skin microbiota communities are shaped by interactions between micro-organisms and a host. In those relations, about 1/3 of the skin microbiota of the population has Staphylococcus aureus as one of the majority bacteria. The main reservoir sites are located at the nasal vestibule (35\%), the perineal region $(20 \%)$, and other regions such as nails, scalp. (5\% to $10 \%$ ) (Torres et al., 2007). These are places where dissemination can occur, causing diseases ranging from small infections of the skin and soft tissues, such as impetigo, folliculitis, and skin abscesses, to potentially fatal diseases such as sepsis, infective endocarditis, or toxic shock syndrome (Tong et al., 2015; Zhen et al., 2020), and can be transmitted to other individuals (Mrochen et al., 2020).

Figure 1 - Morphology of Staphylococcus aureus.

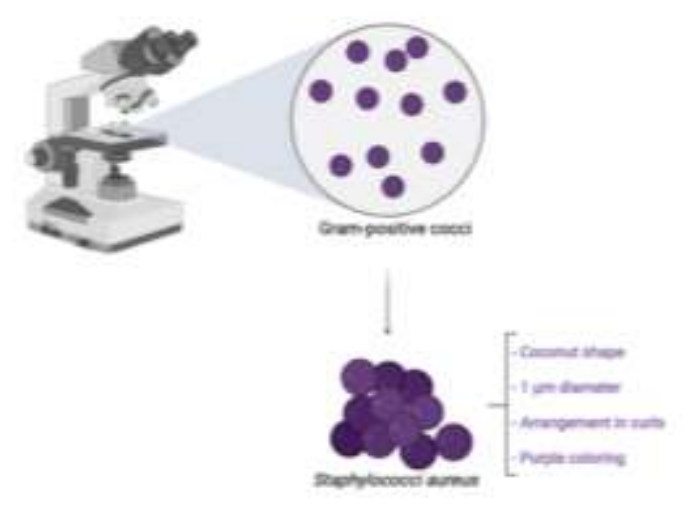

Source: Authors.

The contamination of people by micro-organisms can occur through direct interpersonal or contaminated objects such as towels shared after a shower, athletic equipment shared in the gym, among others. The contact with people-people and people-object facilitates pathogens transport through the skin or nose of asymptomatic carriers. Therefore, it should require basic prevention measures to reduce the incidence and severity of these infections-simple actions such as using a hand sanitizer, washing hands, and controlling environmental sources such as disinfection of the equipment before and after the use. As a result, those are low-cost manner promotes successfully preventing transmission and outbreaks of disease in health facilities (Torres et al., 2007; Mrochen et al., 2007; Mrochen et al., 2007).

Environment disinfection and hand antisepsis with alcohol, without previous application of soap and water, have been widely adopted and used in Brazil (Santos et al., 2007; Brasil et al., 2015). In implementing these measures, 70\% ethyl alcohol plays a fundamental role, as antiseptics and disinfectants, due to its reduced cost, low toxicity, and ease of acquisition and application. Therefore, the study sought to investigate the index of Staphylococcus aureus equipment of a gym of physical activities and identify the level of knowledge about the importance of cleaning equipment. 


\section{Methodology}

The search for Staphylococcus aureus is a cross-sectional, exploratory, experimental, descriptive study with a quantitative approach, carried out in an academy in the city of Alfenas, MG; approved by the Ethics Committee for Research on Human Beings at the José do Rosário Vellano University (UNIFENAS), Alfenas, Minas Gerais, Brazil, with CAAE: 51114315.0.0000.5143, document $\mathrm{N}^{\circ}$ 1.575.682.

\subsection{Sampling}

In the bodybuilding gym in Alfenas, Minas Gerais, Brazil; fifty-four Samples were collected from $7 \mathrm{pm}$ to $10 \mathrm{pm}$ during one day, divided into three periods between 19-20h, 20-21h, and 21-22h. The analyze was based on 3 samples of the same spot in those 3 differets periods. Those selected objects were gym mat, leg press, shin pad, dumbbells, ergometric bicycle, and flexor table. A questionnaire was applied to assess whether users know about the importance of hygiene. They were randomly selected and asked to sign the Informed Consent Form.

\subsection{Staphylococcus aureus analysis}

\subsubsection{Sample dilution}

The analyzed material was collected using sterile swabs moistened in $9 \mathrm{~mL}$ of lactose broth. The swabs introduced in $9 \mathrm{~mL}$ test tubes of sterile lactose broth were considered the $10^{-1}$ dilution, and from this, they will proceed to the dilutions up to $10^{-3}$.

\subsubsection{Morphophysiological characterization}

Serial dilutions, previously selected, were plated on Mannitol Salt Agar, applying the surface technique, and cultured at $35^{\circ} \mathrm{C}$ for 24 to 48 hours. After the incubation period, colonial morphology and bacterioscopy were analyzed using the Gram stain method (Silva, 2010).

\subsubsection{Confirmation of typical colonies}

First, samples were collected and submitted to confirmatory testing for identification. Second, characteristic colonies were selected and inoculated into tubes containing Brain Heart Infusion Agar (BHI). For final, all tubes were incubated at $35^{\circ} \mathrm{C}$ for 24 to 48 hours. Then, the positives were submitted to catalase and coagulase tests. (Silva, 2010).

\section{Results and Discussion}

The research was conducted in a gym in Alfenas-MG, and the analyses were carried out at the Laboratory of Biology of Microorganisms at UNIFENAS, Alfenas, Minas Gerais, Brazil. The analysis of Staphylococcus aureus obtained as a result:

Fifty-four samples were collected, diluted, and planted in Mannitol Salt Agar, a micro-organism gown in only 29. This growth occurred in different collected samples, and at different periods and equipment, 53.70\% of samples have grown. After growth, gram staining was performed to characterize the morphology. It was found 29 stains, all were gram + being an indicator of Staphylococcus aureus in $100 \%$ of the stained samples.

The equipment had an average count ranging from $3 \times 10^{2}$ to $30 \times 10^{2} \mathrm{UFC} / \mathrm{mL}$, as shown in Table 1 . 
Table 1 - Average result of the growth of Staphylococcus aureus per equipment.

\begin{tabular}{l|c}
\hline \multicolumn{1}{c|}{ Equipment } & S. aureus $(\mathbf{U F C} / \mathbf{m L})$ \\
\hline Gym mat & $8,8 \times 10^{2}( \pm 7,9)$ \\
Leg press & $3,0 \times 10^{2}( \pm 4,4)$ \\
Shin pad & $5,7 \times 10^{1}( \pm 4,6)$ \\
Dumbbells & $5,0 \times 10^{2}( \pm 3,8)$ \\
Ergometric bicycle & $1,8 \times 10^{2}( \pm 2,6)$ \\
Flexor table & $30 \times 10^{2}( \pm 1,9)$ \\
\hline Total & $2,2 \times 10^{3}$ \\
\hline
\end{tabular}

Source: Authors.

Catalase and coagulase tests confirm that 29 of 54 samples were from Staphylococcus aureus species. In a total of $46 \%$ of positive samples, as shown in Table 2.

Table 2 - Results of the analysis of colonial morphology, bacterioscopy, through Gram Stain, Brain and Heart Infusion Agar (BHI) and Confirmatory tests of Catalase and Coagulase.

\begin{tabular}{c|c|c|c|c}
\hline Sample & Gram & BHI & Catalase & Coagulase \\
\hline A01 & + & + & + & + \\
A02 & + & + & + & + \\
A03 & + & + & + & + \\
A04 & + & + & + & + \\
A05 & + & + & + & + \\
A06 & + & + & + & + \\
A07 & + & + & + & + \\
A08 & + & + & + & + \\
A09 & + & + & + & + \\
A10 & + & + & + & + \\
A11 & + & + & + & + \\
A12 & + & + & + & + \\
A13 & + & + & + & + \\
A14 & + & + & + & + \\
A15 & + & + & + & + \\
A16 & + & + & + & + \\
A17 & + & + & + & + \\
A18 & + & + & + & + \\
A19 & + & + & + & + \\
A20 & + & + & + & + \\
A21 & + & + & + & + \\
A22 & + & + & + & + \\
A23 & + & + & + & + \\
A24 & + & + & + & + \\
A25 & + & + & + & + \\
A26 & + & + & + & + \\
A27 & + & + & + & + \\
A28 & + & + & + & + \\
A29 & + & + & + & + \\
\hline & & + & &
\end{tabular}

Source: Authors. 
The enzyme breaks down hydrogen peroxide $\left(\mathrm{H}_{2} \mathrm{O}_{2}\right)$ in the catalase test, resulting in water and oxygen. Bacteria are mixed with $\mathrm{H}_{2} \mathrm{O}_{2}$. For this reason, when it is a catalase-positive bacteria, bubbles appear due to oxygen, in response to strains of Staphylococcus aureus and/or Staphylococcus epidermidis, whereas, in negative-catalase bacteria, bubbles don't appear in response to Streptococcus viridans and/or Streptococcus pneumoniae present. In the performance of coagulase, we have Staphylococcus aureus for positive coagulase and Staphylococcus epidermidis for negative coagulase (Brasil, 2015; Mrochen et al., 2020).

We performed biochemical tests with positive samples for both catalase and coagulase test as for the $53.70 \%$ contamination by the micro-organism Staphylococcus aureus. These become potentially pathogenic bacteria when presented ports of entry or pathologies that predispose the development of more severe infection (Santos, 2007).

It is estimated that $30 \%$ of the United States population is colonized by Staphylococcus aureus, and $1.5 \%$ of this bacterium is methicillin-resistant Staphylococcus aureus (MRSA). In Brazil, there are no systematized data showing colonization rates in the general population, and some studies were developed in specific populations (for example, in patients seen at a dermatology clinic) indicate the prevalence of Staphylococcus aureus ranging from $15.5 \%$ to $68.79 \%$ (Oliveira; Paula; 2012; Mrochen et al., 2020).

Similar research in supermarkets in Japan showed 52 strains of Staphylococcus aureus in shopping basket handles and 91 strains in the hands of employees of these locations. Thus the incidence of strains of S. aureus in the community is becoming a big problem (Oliveira, et al., 2015).

Moreover, the Staphylococcus aureus remains an important pathogen, accounting for more than $30 \%$ of cases of hospital infections, where colonized patients represent reservoirs, employees, and the environment itself (Mundin, et al., 2003; Zhen et al., 2020).

Staphylococcus aureus is considered the principal causative agent of infections acquired in the community and the hospital environment. This micro-organism represents one of the most frequent causes of healthcare-associated infections reported by The National Nosocomial Infection Surveillance System (USA), including ventilation-associated pneumonia, surgical site infections, and catheter-associated bacteremia (Ferreira, et al., 2011).

In this context, a study aimed to identify the micro-organisms present in toys used in hospital therapeutic teaching corroborates the data obtained in this study regarding the presence of $68.25 \%$ of micro-organisms in toys plastic and $59.26 \%$ for cloth (Nicolau, 2014).

In a city in southeastern Brazil, a study of the infectious potential of public transport was carried out, with the presence of two buses, which resulted in the presence of Staphylococcus negative coagulase, followed by Staphylococcus aureus, we can thus infer and supporting this study carried out in academia that the presence of Staphylococcus aureus is significant in terms of handling public vehicles (Fernandes, et al., 2012).

Therefore, it is worth reinforcing measures to reduce the incidence of micro-organisms, especially the Staphylococcus aureus is the use of $70 \%$ alcohol and disposable paper before and after using equipment in the gym, and to remind for the need for applications of $70 \%$ alcohol should be for ten to twenty seconds to be effective in preventing the transmission of grampositive bacteria, such as Staphylococcus aureus (Santos, et al., 2007; Zhen et al., 2020).

However, with a smaller margin of efficiency, it is noteworthy that tests carried out in the hands of professionals who work in the intensive care unit of a hospital after washing and antisepsis with only $70 \%$ alcohol point to the low efficacy of the product (Vilarinho, et al., 2015).

The use of $70 \%$ alcohol is a modern cleaning method, as it is a simple, relatively quick, and low-cost process to the destruction of micro-organisms. However, the use of alcohol, which is considered an intermediate-level disinfectant, is often overestimated, probably due to its ease of access (Venturelli, et al., 2009). 
Unlike the product used in this study, being $70 \%$ alcohol, research that aimed to identify the prevalence of Staphylococcus aureus in an advanced life support ambulance fleet highlighted the importance of cleaning the ambulance using chlorine at regular intervals, where $70 \%$ of the ambulances were contaminated by the bacteria (Prata, et al., 2016).

A relevant scientific production was found, it is worth highlighting research that sought to analyze the contamination of intensive care unit devices before and after the cleaning routine and a study that evaluated the cleaning of stethoscopes used by doctors and nurses. Highlight the efficiency of $70 \%$ alcohol in the devices evaluated where its efficiency on the proliferation of Staphylococcus aureus was total in the fight against the bacteria (Cordeiro, et al., 2015).

For a general analysis, the questionnaire was applied to find out if gym attendees (24 participants) use any method of disinfection of equipment (Figure 2A) and which method is most used by them (Figure 2B). Of 24 volunteer research participants, only $9(37.5 \%)$ reported cleaning the equipment, while the vast majority (12 (50\%)) of respondents do not use this procedure; 3 individuals $(12.5 \%)$ sometimes perform the cleaning (Figure 2A). The group of participants who clean (9) and who sometimes clean their equipment (3), 6 of this group (50\%) use only the individual towel on the equipment, while the others $(6(50 \%))$ use disposable paper plus $70 \%$ alcohol (Figure $2 \mathrm{~B})$.

Figura 2 - Questionnaire applied to volunteer research participants.

\section{A)}

12

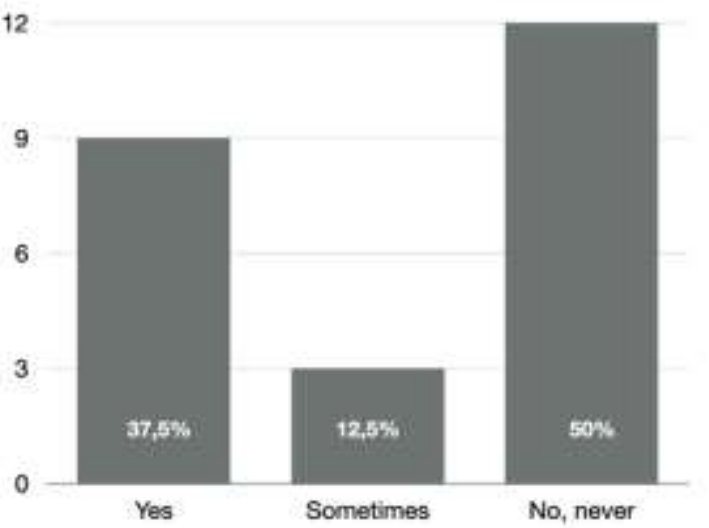

B)

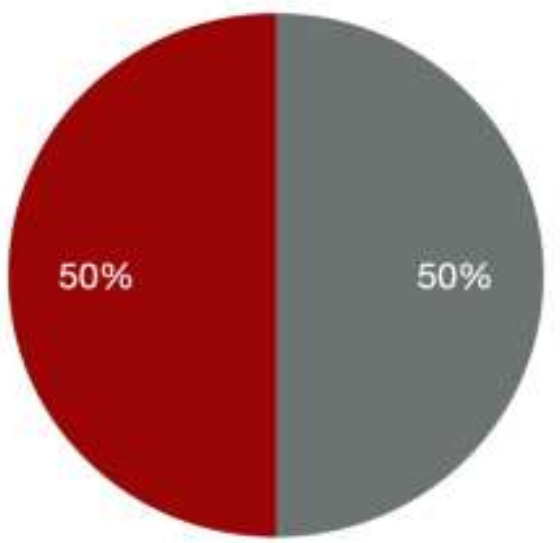

(A) Do you gym practitioners sanitize equipment? 37.5\% Yes, $12.5 \%$ sometimes, $50 \%$ no, never. (B) What cleaning method do you use during training? 50\% (in gray) use individual towels, $50 \%$ (in red) use disposable paper, and $70 \%$ alcohol.

Source: Authors.

Among the study, 24 gym attendees participate in the survey answered by this questionnaire, having therefore signed the Informed Consent Term.

\section{Conclusion}

The data revealed contamination of the equipment, suggesting that many micro-organisms from the athletes' skin microbiota may remain in the devices, leading to infections for the community. The percentage of surface contaminated by Staphylococcus aureus in the analyzed devices was approximately 53.70\%. Even though we are aware that the safe method, according to ANVISA, is using 70\% alcohol and disposable paper in all equipment before and after use, this type of cleaning is not used by those present in physical activity establishments. $50 \%$ of respondents, gym-goers, do not use cleaning equipment, 
and the other $50 \%$ only use the individual towel. However, they are aware that their attitude can be harmful to health if the equipment has pathogens. Therefore, it is concluded that the measures that can reduce the incidence of micro-organisms, especially Staphylococcus aureus, is to use $70 \%$ alcohol and disposable paper before and after using the equipment in gyms.

We indicate, after the survey, that gyms make available $70 \%$ alcohol and disposable paper near all the equipment so that those who go there can carry out proper hygiene. It would also be interesting if there was a small bulletin on each device describing the correct method of application, and warning that, after application, the user has 10 to 20 seconds to use the equipment free of pathogens.

\section{Acknowledgments}

We thank the José do Rosário Vellano University. This work was carried out with the support of the Coordination for the Improvement of Higher Education Personnel - Brazil (CAPES) - Financing Code 001 and the National Council for Scientific and Technological Development - Brazil (CNPq).

\section{References}

Brasil, A. (2015). Resistência microbiana - Mecanismos e impacto clínico (II. Gram positivos - resistência aos antimicrobianos). http://www.anvisa.gov.br/servicosaude/controle/rede_rm/cursos/rm_controle/opasweb/modulo3/gramp_stap hylo.htm

Chen, P., He, G., Qian, J., Zhan, Y., \& Xiao, R. (2020). Potential role of the skin microbiota in Inflammatory skin diseases. J Cosmet Dermatol, 00, 1-10.

Cordeiro, A. L., Oliveira, M. M. C, Fernandes, J. D., Barros, C., \& Castro, L. M. C. (2015) Contaminação de equipamentos em unidade de terapia intensiva. Acta Paul Enferm., 28(2), 160-5.

Everton, G. O., Rosa, P. V. S., Neves, S. C., Pereira, A. P. M., Lima, E. C. S. et al. (2020). Chemical characterization, antimicrobial activity and toxicity of essential oils of Pimenta dioica L. and Citrus sinensis L. Osbeck. Research, Society and Development, 9(7): 1-18, e803974842.

Fernandes, A. A., Rangel, C. D., Sena, C. J. C., Rangel, C. V., \& Moraes, R. (2012). Diversidade de Bactérias, Fungos e Formas de Resistência de Parasitos em Duas Rotas de Ônibus do Transporte Coletivo da Grande Vitória-ES. Revista Sapientia., 11, 39-45.

Ferreira, A. M., Andrade, D., Almeida, M. T. G., Cunha, K. C., \& Rigotti, M.A. (2011). Colchões do tipo caixa de ovo: um reservatório de Staphylococcus aureus resistente à meticilina? Rev Esc Enferm USP., 45(1), 161-6.

Laddu, D. R., Lavie, C. J., Phillips, S. A., \& Arena, R. (2021). Physical activity for immunity protection: inoculating populations with healthy living medicine in preparation for the next pandemic. Prog Cardiovasc Dis. 64, 102-104

Mundim, G. J., Dezena, R. A., Oliveira, A. C. S., Silva, P. R., Cardoso, M., Pereira, G. A., Morais, C. A., Terra, A. P. S. et al. (2003). Avaliação da presença de Staphylococcus aureus nos leitos do Centro de Terapia Intensiva do Hospital Escola da Faculdade de Medicina do Triângulo Mineiro, em relação à posição no colchão antes e após a limpeza. Rev. Soc. Bras. Med. Trop., 36(6), 685-688.

Nicolau, E. M. (2014). Dissertação de Mestrado. Guarulhos: Universidade de Guarulhos; 50p.

Nieman, D. C., \& Wentz L. M. (2019). The compelling link between physical activity and the body's defense system. J Sport Health Sci., 8(3), $201-17$.

Oliveira, A. C., \& Paula, A.O. (2012). Descolonização de portadores de Staphylococcus aureus: indicações, vantagens e limitações. Texto Contexto Enferm., $21(2), 448-57$.

Oliveira, D.B., Bombana, C. C., Rodrigues, G. A. G, Gonçalves, R. J., \& Parussolo, L. (2015). Caracterização de Staphylococcus aureus isolados da barra de mão de carrinhos e alças de cestas de supermercados. Rev Ciênc Farm Básica Apl., 36(3), 407-412.

Prata, R. A., Simão, E. P., Chadi, P. F., Tavares, A. L. G., Benedetti, N. A., Orso, L. F., Caldeira, S. M., Carvalho, G. C., \& Corrêa, I. (2016). Higienização de unidade móvel de saúde. Vigil. sanit. Debate., 4(2), 51-55.

Santos, A. L., Santos, D. O., Freitas, C. C., Ferreira, B. L. A., Afonso, L. F., Rodrigues, C. R., \& Castro, H. C. (2007). Staphylococcus aureus: visitando uma cepa de importância hospitalar. J Bras Patol Med Lab., 43(6), 413-

Silva, L. G. M. (2010). Avaliação microbiológica da merenda escolar do município de Alfenas- MG e das mãos de seus manipuladores. Dissertação Mestrado (mestrado em ciências da saúde), Universidade José do Rosário Vellano, 65p. 
Silveira, M. P., Fagundes, K. K. S., Bizuti, M. R., Starck, E., Rossi, R. C., \& Silva, D. T. R. (2021). Physical exercise as a tool to help the immune system against COVID-19: an integrative review of the current literature. Clinical and Experimental Medicine., 21, 15-28

Tong, S. Y. C., Davis, J. S., Eichenberger, E., Holland, T. L., \& Fowler, V. G. (2015). Staphylococcus aureus infections: Epidemiology, pathophysiology, clinical manifestations, and management. Clin. Microbiol. Rev., 28, 603-661.

Torres, A. M., Ritter, A. M. V., Volpe, A. T. V., \& Tognim, M. C. B. (2007). Contaminação por Staphylococcus aureus resistentes a oxacilia (orsa) nos equipamentos atléticos das academias. VEPCC Cesumar., 1-5.

Tortora, G. J. Microbiologia. (10a ed.), Artmed, 2012.

Venturelli, A. C., Torres, F. C., Almeida, R. R., Almeida, R. R., Almeida, M. R., Ferreira, F. P. C. (2009). Avaliação microbiológica da contaminação residual em diferentes tipos de alicates ortodônticos após desinfecção com álcool 70\%. R Dental Press Ortodon Ortop Facial., 14(4), 43-52.

Vilarinho, L. M., Vilarinho, M. L. C. M., Silva, F. L., Guimaraes, M. S. O, \& Leal, A. C. A. M. (2015). Isolamento de Staphylococcus aureus em mãos de profissionais de Unidades de terapia Intensiva. Rev. Pre. Infec e Saúde., 1(1), 10-18.

Zhen, X., Lundborg, C. S., Zhang, M., Sun, X., Li, Y., Hu, X., Gu, S., Gu, Y., Wei, J., \& Dong, H. (2020). Clinical and economic impact of methicillinresistant Staphylococcus aureus: A multicentre study in China. Sci. Rep., 10, 3900. 